\title{
Ancient Egyptian Footwear at the Agriculture Museum, Giza
}

\author{
Mona M. Taha Hussein \\ Faculty of Tourism and Hotel Management, October 6 University, Egypt.
}

\begin{abstract}
Ancient Egyptian Footwear is not only a protective foot covering but also has a considerable symbolic content. Manufacturing technology of the ancient Egyptian footwear was systematically studied by the Ancient Egyptian Footwear Project (AEFP). The collection is exhibited but is not presented as it should be. Furthermore, visitors of the museum have no opportunity to observe this collection since the building is closed $^{1}$. The ancient Egyptian Footwear collection (Table) housed in one of the new agriculture museums buildings in Giza that comes mainly from Deir el Madina includes 17 sandals and 2 open shoes. Comparing the collection with other Ancient Egyptian Footwear showed that the collection should fall in the New Kingdom.
\end{abstract}

\section{Introduction}

The ancient Egyptian collection housed in one of the New Museums buildings of the Agriculture Museum in Giza, includes 17 sandals and two open shoes. Most of the Footwear collection at the museum comes from Deir el Madina in Luxor, and others were bought from bazaars or were given as presents from excavations in the years 1933 -35. It is difficult to confirm that the objects dated in the register as New Kingdom or later were actually found in the New kingdom deposits of Deir el Madina or in deposits that date back to later periods. Gourlay (1981 ) describes four sandals (JE.2317, JE.2594, JE.2598, and JE.2875) from the collection. In El Hadidi and Hamdy (2011) two sandals (JE.2317 and JE.2601) and two shoes (JE.2595, JE.2596) from the collection were also studied. El Hadidi and Hamdy (2011) as well as Velmeijer's research (Velmeijer 2006-2011) which is a part of the ancient Egyptian footwear project focuses on the technological aspect. The aim of this paper is to describe the ancient Egyptian footwear collection at the agriculture museum, Giza, trying to date it through a comparative study with other Footwear ${ }^{2}$.

\section{The Development of the ancient Egyptian Footwear}

In ancient Egypt sandals were a common commodity despite the fact that people must have been used to walking on bare feet. The Ancient Egyptian wore Sandals to protect their feet when walking or working outside. They were generally chosen for outdoor activities and, in a funerary context, may have been reflective of the ability of the deceased to leave the tomb (Lyn , 2001).

In the iconography the sandals occur on both faces of the Narmer palette (3100 B.C.). The King is shown barefoot but followed by his sandal-bearer. Examinations of the Old Kingdom Tomb relief have indicated that context could have played a larger role than social status in whether or not sandals were worn by the elites, and that personal preference also influenced their usage. The professional care of feet existed in ancient Egypt as evidenced by relief carvings at the entrance to Ankhmahor's tomb, 6 Dynasty, where work on hands and feet is depicted.

1 I would like to thank Mr. Mohamed el Hossainy el Akaad, General supervisor of the Agricultural Museum for the permission to photograph the Footwear collection

2 The study is based on photographs taken by the author, and the data written in the JE of the Museum. Footwear is referred to by its JE number. 


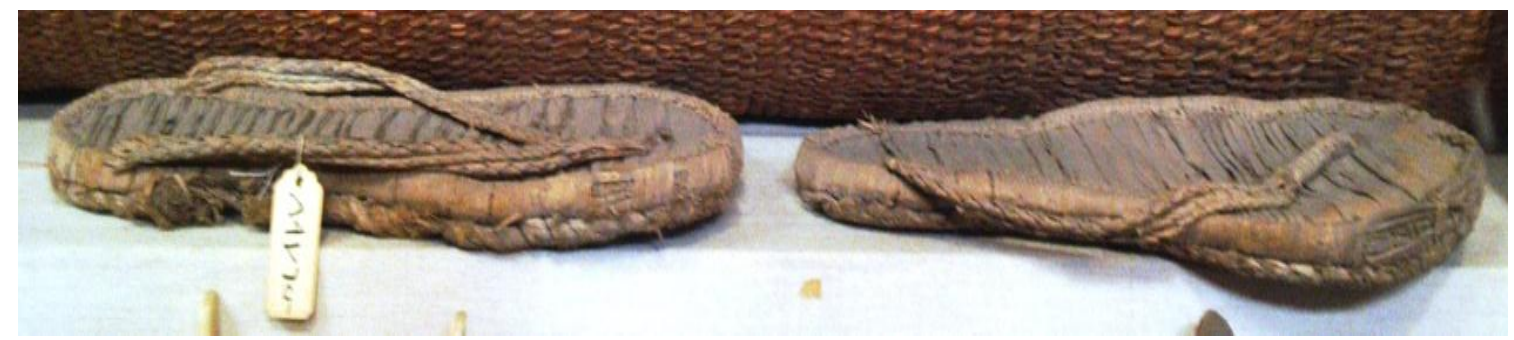

The Footwear collection at the Egyptian Museum, Cairo, includes a pair of sandals (Fig.1) which dates back to the Old Kingdom ${ }^{1}$ and is exhibited in the upper floor, hall 48 of the museum.

From the Middle Kingdom the sarcophagus of Dagi, JE 25328 and of Ashait JE47267 are exhibited at the Egyptian Museum, Cairo in the upper floor, hall 48. Also model sandals were put in the coffins with the mummy. There are indications that royals wore other footwear, also, texts refer to sandals for priests as well as sandals for men, women and Children.

In the New Kingdom sandals suddenly began to appear on the hieroglyphs depicting scenes of Egyptian life, like in Rekhmire Tomb (TT100) and in the Tomb of vizier Useramun (TT61). One variation has its own name (twtcfnw), enveloping sandals. Footwear of this type was found in the Tomb of Yuia and Thiiu (KV46). Men and women could wear such sandals. Egyptians had developed advanced shoemaking skills for their time, and they created sandals woven of reeds or leather that were quite similar in design to many modern sandals. Sandals were often connected to purity. For instance, the Bd: Ch- 125 required the deceased to be 'pure and clean... shod in white sandals' before reciting the spell. White sandals were used in ritual contexts, often being mentioned in the Netherworld literature as a necessary attribute of the righteous deceased. Solid gold sandals intended for funerary use were found in the New Kingdom (Lyn, 2001). They were shown on the King's feet in some late Eighteenth Dynasty Tomb reliefs. Most of these are plain but several are elaborately decorated. The embellishments are of two types. They either relate to the control of chaos (through bound prisoners, bows - representative of the Nine Bows, the traditional enemies of Egyptand sema-tawy symbols, which show the binding together of the Two Lands of Egypt) or the decoration representing the result of the successful maintenance of cosmic balance (Veldmeijer 2011). Texts such as the Pap. Haris I show us that sandals were not rare, they were made of plant and leather materials. The manufacturing techniques of the sandals were fairly limited but the variation in forms is quite large (Veldmeijer 2010). There are four types of straps, but the differences are not distinguishable in the language (2008). The four identified plant species, $\mathrm{H}$ thebaica Mart., P.dactylifera L., c. papyrus L. and d. bipinnata (L) sapf., were native to Egypt during the Pharaonic period among which three are still used today in the manufacture of the baskets, bags and ropes ( Hadidi and hamdy 2011). Footwear made of plant materials was more frequently used than leather .Again Footwear varied from simple eared sandals, to open shoes made of leather, and from sewn sandals to open shoes made of fiber (Veldmeijer 2010). Workmen and others, received sandals as a part of their pay. Travelers needed footwear and the rules of etiquette stated that sandals were to be removed in the presence of one of superior rank (Jac2008). Moreover, there are clear differences in footwear from Egypt and the Near East although the shape changed through time (Veldmeijer 2010). 


\section{Description}

The Footwear collection at the agriculture museum: The specimen number, locality, Description, measurements, Photo.

\begin{tabular}{|c|c|c|c|c|}
\hline $\begin{array}{l}\text { Inventor } \\
\text { Number }\end{array}$ & Provenance & Description & Length & Photo \\
\hline $\begin{array}{c}\text { JE } 1471 \\
\text { Box.no.30 }\end{array}$ & $\begin{array}{l}\text { Deir el } \\
\text { Madinah } \\
\text { Thebes }\end{array}$ & $\begin{array}{c}\text { Three sewn-edge plaited sandals } \\
\text { of Halfa, date palm leaves. } \\
\text { Donated by the French institute, } \\
\text { I.F.A.O }\end{array}$ & $\begin{array}{l}\text { A: L. } 31 \mathrm{~cm} \\
\text { B: L. } 33 \mathrm{~cm} \\
\text { C: L. } 32 \mathrm{~cm}\end{array}$ & \\
\hline $\begin{array}{l}\text { JE } 4369 \text { Box } \\
\text { no. } 30 \\
\text { A.B }\end{array}$ & unknown & $\begin{array}{l}\text { Pair of coiled sewn sandals of } \\
\text { Dom, palm leaves- dom leaves }\end{array}$ & L. $29 \mathrm{~cm}$ & \\
\hline $\begin{array}{c}\text { JE } 2317 \\
\text { Box no.30 }\end{array}$ & $\begin{array}{l}\text { Deir el } \\
\text { Madinah } \\
\text { Thebes }\end{array}$ & $\begin{array}{l}\text { Sewn- edge plaited sandal } \\
\text { Cyperus } \\
\text { papyrus(bundle)\&Hyphaene } \\
\text { Thebaica (wrapping strip) }\end{array}$ & L. $32 \mathrm{~cm}$ & \\
\hline JE 2319 & unknown & $\begin{array}{l}\text { Swen -edge plaited sandal of } \\
\text { dom palm leaves }\end{array}$ & L. $29 \mathrm{~cm}$ & \\
\hline $\begin{array}{l}\text { JE } 2427 \text { Box } \\
\quad \text { no. } 30\end{array}$ & $\begin{array}{l}\text { Bought at } \\
\text { Luxor }\end{array}$ & $\begin{array}{c}\text { Sewn -edge plaited sandal of } \\
\text { date palm leaves }\end{array}$ & L. $26 \mathrm{~cm}$ & \\
\hline JE 2594 & $\begin{array}{l}\text { Dei rel } \\
\text { Madinah } \\
\text { Thebes }\end{array}$ & $\begin{array}{l}\text { Sewn -edge plaited sandal of } \\
\text { Dom palm leaves }\end{array}$ & L. $35 \mathrm{~cm}$ & \\
\hline $\begin{array}{c}\text { JE } 2595 \\
\text { Box no.30 }\end{array}$ & $\begin{array}{c}\text { Deir el } \\
\text { Madinah } \\
\text { Thebes } 1933\end{array}$ & $\begin{array}{l}\text { Full upper open shoe of Dom } \\
\text { palm leaves }\end{array}$ & L. $29,5 \mathrm{~cm}$ & \\
\hline $\begin{array}{c}\text { JE } 2596 \\
\text { Box no.30 }\end{array}$ & unknown & $\begin{array}{l}\text { Full upper open shoe of Dom } \\
\text { palm leaves, and papyrus }\end{array}$ & L. $30.5 \mathrm{~cm}$ & \\
\hline $\begin{array}{c}\text { JE } 2597 \\
\text { Box no. } 30\end{array}$ & unknown & $\begin{array}{l}\text { Sewn -edge plaited sandal of } \\
\text { Dom palm leaves }\end{array}$ & L. $28.5 \mathrm{~cm}$ & \\
\hline
\end{tabular}




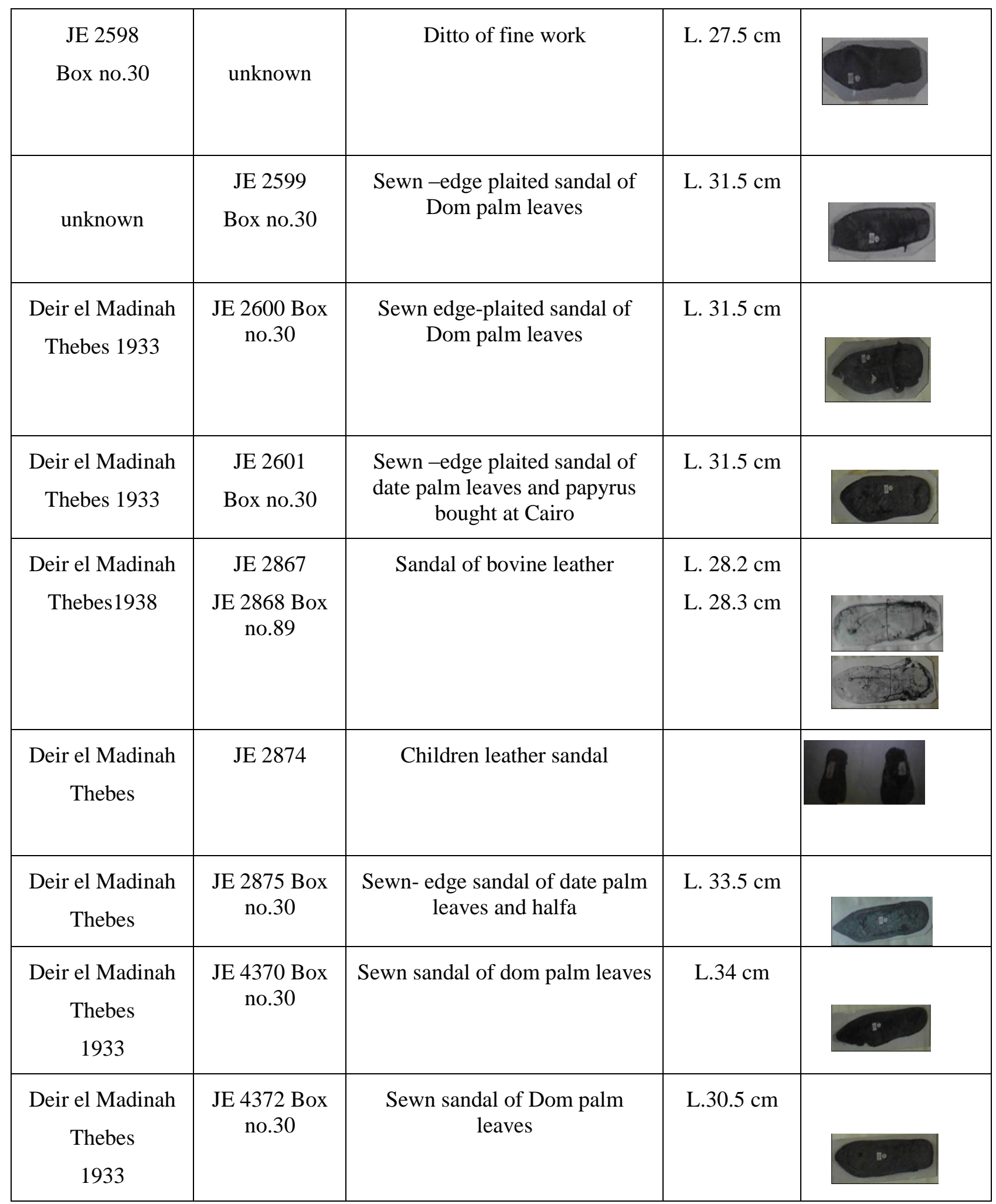

\section{Sandals}

Several types of footwear from ancient Egypt have been published by the AEFP, it is possible to present a comparison among some of them. 


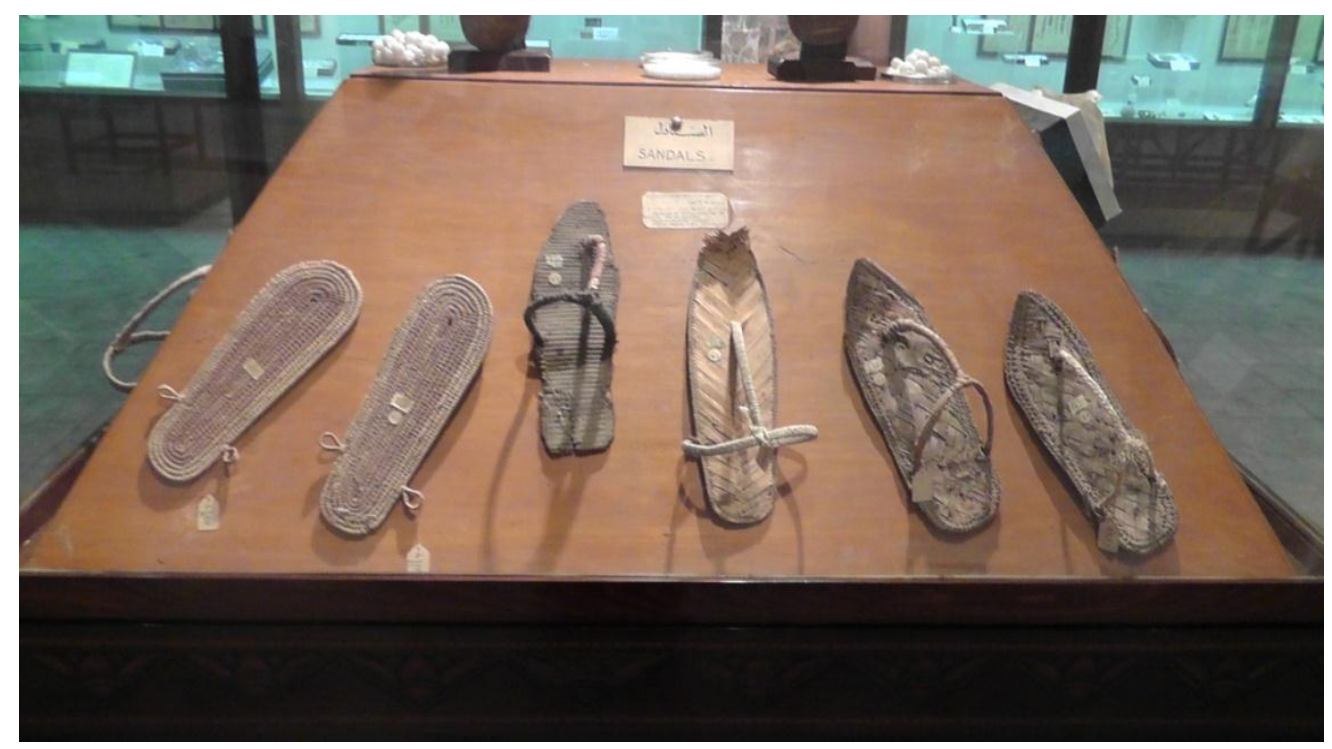

Fig.1.a) coiled sandal, JE 4369 b) sandal, JE2598 c)sewn edge plaited sandal, JE2594 d)sewn edge plaited sandal, JE4370 f) sewn edge plaited sandal, JE 4372.

(Photograph Mona Hussein)

Sewn-edge plaited sandal

The sandals JE 4372, JE 2597, JE 2427, and JE 2595, were found in Deir el Madina, made out of palm leaf, grass and papyrus, are short with a square or rounded heel from which, towards the front the width increases gradually. It has its largest width approximately at the insertion of the front strap. At the front, the lateral and medial sides run diagonally towards the pointed toe, which is positioned more or less in the centre of the width of the sole. The off centre position of the front strap indicates the orientation. The sandals JE 1471, JE 2594, JE 2875, and JE 4370, were found in Deir el Madina, made of palm leaf, grass and papyrus, are more elongated but based on the same principle.

\section{Comment}

Several sandals have been excavated from Deir el -Medinah, dating them firmly to the 18-20 Dynasty (Gourlay 1981) ${ }^{1}$. Veldmeijer (2010) re-classified Gourlay's type A, B, C, and palatine sandals in the AEFP's category sewn-edge plaited sandals. These sandals were so important that they were even imitated in gold. It has one thing in common. The fabric might be folded to create thicker sole. The sole layers are held together within an edge that consists of cores that sandwich the sole layers and are sewn with small strips of palm leaf, comparable to the edge in sewn sandals (sandal, JE 4369) to which the back straps are attached (Veldmeijer 2010). The plain plaited sandals (Veldmeijer 2008/2009) differ in this construction form because these sandals consist of folded fabric without a sewn edge. They were a status symbol, only used by those elite who were rewarded by the king and royalty. The category sewn-edge plaited sandal is a large varied group, which includes several different types based on the shape and, to a lesser extent, technological features $^{2}$

\section{Coiled sewn sandals}

The Pair of coiled sewn Sandals, JE 4369 in Box no.30 AB, 29 cm, made out of Dom, palm leaves, L. 29 cm, province unknown. A length of fabric is coiled and secured by means other than wrapping and sewing.

\section{Comment}

${ }^{1}$ JE. 2598, JE 2317, JE 2594, JE 2875, are comparable with R.2539. R.2592, Gourlay 1981. 
The sole construction of the coiled sandals is relatively simple. The only Type dated before the Roman period is the Plied string (Veldmeijer 2011).

Leather sandals

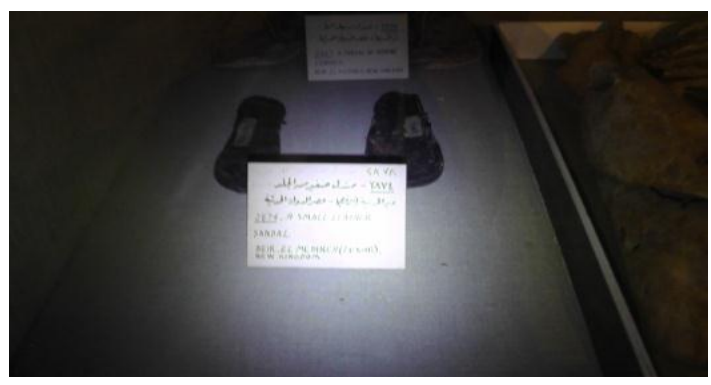

Fig.4 a) a pair of small sized leather sandal, JE 2878

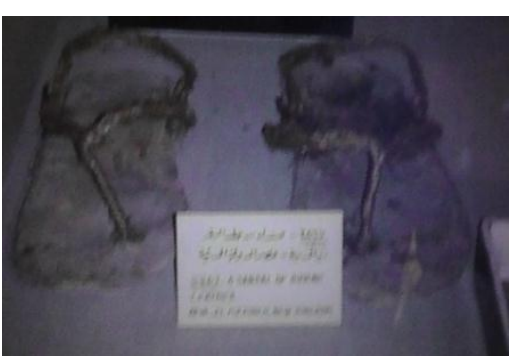

b) a pair of leather sandal, JE 2867, JE 2868

(Photograph Mona Hussein)

The Pair of sandals, JE 2867, JE 2868 Box no.89 are made out of bovine leather, L. $28.2 \mathrm{~cm}$, Deir el Madinah, Thebes1938. The leather sandals JE 2867, JE 2868are similar to the sandals AEPB AM 054a, and AEPB AM 054b,

\section{Comment}

We can see the priests who carry the barque are shod in leather sandals. The leather sandals were less than the fiber ones. Leather sandals were mainly for priests and the papyrus one for the lower personal (Jac 2008).

\section{Open shoes}

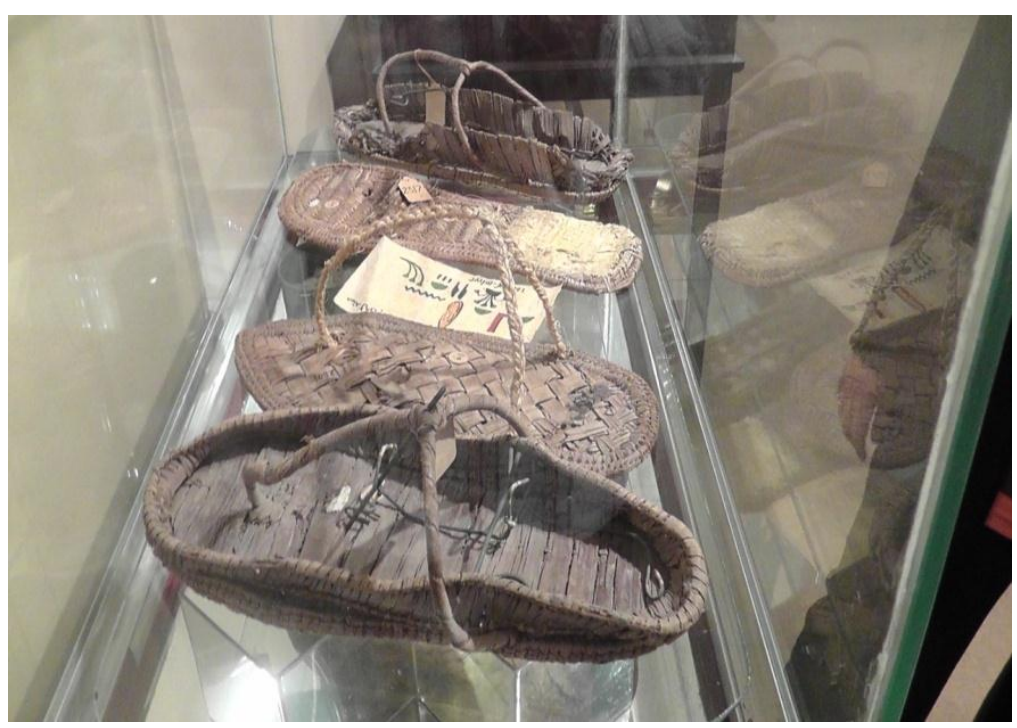

Fig.3. a) open shoe, JE 2596 b) sewn edge-plaited sandal, JE2601 c) sewn sandal, JE 2317 d) open shoe, JE 2595

The two full upper open shoes are made of fiber. Their shape is longitudinally almost symmetrical and straight, but the front edge diverges outwards and terminates in a rounded toe, from which the width at both sides does not increase towards the front in shoe JE2595 and increases in shoe JE 2596. There is no constricted waist in both shoes. The sole in both shoes consisted of two layers. 


\section{Comment}

Two categories of shoes can be distinguished in ancient Egypt. Open shoes and closed shoes. The open shoe is the only category which we have at the Museum's collection and is made of fibre as well.

\section{Conclusion}

The 17 sandals from the collection (see the Table) that have been studied can be divided in 2 types on the basis of the shape and the sole construction. Type 1 sewn sandals made of plant materials (15 sandals) and leather ( 2 sandals). The type of the shoe is the open shoes which is made of fibre. All the collection can be dated to the $18-20$ Dynasty. The Footwear collection has to be well exhibited and labeled through the Museum coordinators. The tour operators who are interested and specialized in the therapeutic and curative tourism should be aware of the importance of the footwear collection at the agriculture museum, Giza. Imitating the ancient Egyptian footwear and using the medical modern comfortable rubber insoles will combine authenticity with modern comfort.

\section{Bibliography}

Donald P. R. (1988), Papyrus, in: The Biblical Archaeologist, Vol.51, No.3, pp.132-140.

Gourlay, Y.J.-L. (1981), Les sparteries de Deir el-Médineh xviiie-xxe dynasties, I : Catalogue des techniquesde sparterie. Cairo: IFAO.

Jac, J. (2008), Daily Dress at Deir el-Madina, London, pp. 95-108.

Lyn, G. (2001), Footwear, in: The Oxford Encyclopedia of ancient Egypt, vol.1: American University in Cairo, p. 278.

Montembault, V. (2000), Catalogue des chaussures de l'antiquité Égyptienne. Paris: Réunion des Musées Nationaux.

El Hadidi NMN and R. Hamdy (2011), Basketry accessories: Footwear, bags and fans in ancient Egypt in: the Journal of Archaeological science, Vol. 38, Issue 5, p.1050-1061.

Teeter, E. ( 2003), Ancient Egypt. Treasures from the Collection of the Oriental Institute, University of Chicago. Oriental Institute Museum Publications 23. Chicago: Oriental Institute.

Veldmeijer, A.J. (2006/7), Studies of Ancient Egyptian Footwear. Technological Aspects. Part I. Cordage Sandals from Qasr Ibrim, JEOL 40, pp. 61-75.

Veldmeijer, A.J. (2007), Studies of Ancient Egyptian Footwear. Technological aspects. Part III. Leather or StringReinforced Plaited Sandals from Qasr Ibrim, JEOL 41.

Veldmeijer, A.J. (2009), Studies of Ancient Egyptian Footwear. Technological aspects. Part IV. Plain Plaited Sandals from Qasr Ibrim, JEOL 41.

Veldmeijer, A.J. (2009), Studies of Ancient Egyptian Footwear. Technological Aspects. Part VI. Sewn Sandals, in a Festschrift volume.

Veldmeijer, A.J. (2010) Studies of Ancient Egyptian Footwear. Technological Aspects. Part XV. Leather Curled-Toe Ankle Shoes, PJAEE.

Veldmeijer, A.J. (2010) Studies of ancient Egyptian footwear. Technological aspects. Part X. Leather Composite Sandals, PJAEE.

Veldmeijer, A.J. (2010) Studies of Ancient Egyptian Footwear. Technological Aspects. Part XII. Fibre Shoes'

Veldmeijer, A.J, with contributions by A.J. Clapham, C.R. Cartwright, E. Endenburg, A.Gräzer, F. Hagen, J.A. Harrell, M.H. Kriek, P.T. Nicholson, J. Ogden and G. Vogelsang-Eastwood.(2011) Tutankhamun's Footwear. Norg: DrukWare. 


\section{النعال المصرية القديمة بالمتحف الزراعى بالجيزة}

ملخص البحث

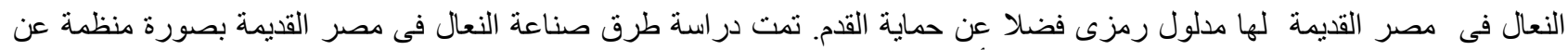

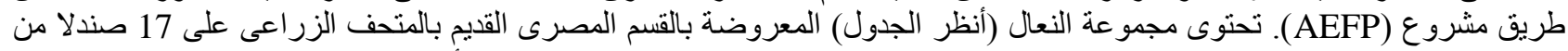

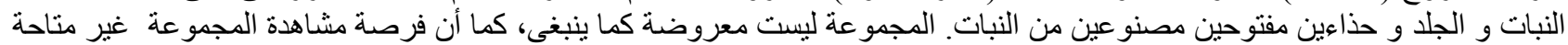

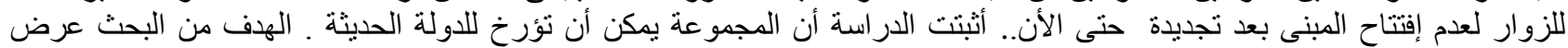
المجمو عة و تأريخها. 